BMJ Open Diabetes Research \& Care

To cite: Hong J-H, Kim D-H, Lee M-K. Glucolipotoxicity and GLP-1 secretion. BMJ Open Diab Res Care 2021;9:e001905. doi:10.1136/ bmjdrc-2020-001905

Received 17 September 2020 Revised 15 December 2020 Accepted 18 January 2021
Check for updates

(c) Author(s) (or their employer(s)) 2021. Re-use permitted under CC BY-NC. No commercial re-use. See rights and permissions. Published by BMJ.

${ }^{1}$ Division of Endocrinology \& Metabolism, Samsung Biomedical Research Institute, Seoul, South Korea

${ }^{2}$ Division of Cell Therapy, Department of Neurosurgery, Seoul National University Bundang Hospital, Seongnam, South Korea

${ }^{3}$ Division of Endocrinology \& Metabolism, Department of Internal Medicine, Uijungbu Eulji Medical Center, Eulji University School of Medicine, Uijungbu, South Korea

Correspondence to Dr Moon-Kyu Lee; leemk4132@gmail.com

\title{
Glucolipotoxicity and GLP-1 secretion
}

\author{
Jung-Hee Hong, ${ }^{1}$ Dae-Hee Kim, ${ }^{2}$ Moon-Kyu Lee (D) ${ }^{3}$
}

\section{ABSTRACT}

Introduction The concept of glucolipotoxicity refers to the combined, deleterious effects of elevated glucose and/or fatty acid levels.

Research design and methods To investigate the effects of chronic glucolipotoxicity on glucagonlike peptide-1-(7-36) amide (GLP-1) secretion, we generated glucolipotoxic conditions in human $\mathrm{NCl}-\mathrm{H} 716$ enteroendocrine cells using either 5 or $25 \mathrm{mM}$ glucose with or without $500 \mu \mathrm{M}$ palmitate for 72 hours. For in vivo study, we have established a chronic nutrient infusion model in the rat. Serial blood samples were collected for 2 hours after the consumption of a mixed meal to evaluate insulin sensitivity and $\beta$-cell function.

Results Chronic glucolipotoxic conditions decreased GLP-1 secretion and the expressions of pCREB, pGSK3 $\beta, \beta$-catenin, and TCF7L2 in NCl-H716 cells. Glucolipotoxicity conditions reduced glucose transporter expression, glucose uptake, and nicotinamide-adenine dinucleotide phosphate (NADPH) levels in L-cells, and increased triglyceride accumulation. In contrast, PPAR $\alpha$ and ATP levels were reduced, which correlated well with decreased levels of SUR1 and Kir6.2, cAMP contents and expressions of pCAMK2, EPAC and PKA. We also observed an increase in reactive oxygen species production, UCP2 expression and Complex I activity. Simultaneous treatment with insulin restored the GLP-1 secretion. Glucolipotoxic conditions decreased insulin secretion in a time-dependent manner in INS-1 cells, which was recovered with exendin-4 cotreatment. Glucose and SMOFlipid infusion for 6 hours decreased GLP-1 secretion and proglucagon mRNA levels as well as impaired the glucose tolerance, insulin and C-peptide secretion in rats. Conclusion These results provide evidence for the first time that glucolipotoxicity could affect GLP-1 secretion through changes in glucose and lipid metabolism, gene expressions, and proglucagon biosynthesis and suggest the interrelationship between glucolipotoxicities of L-cells and $\beta$-cells which develops earlier than that of $L$-cells.

\section{INTRODUCTION}

The primary goal of the treatment of type 2 diabetes mellitus is to control hyperglycemia. However, treatment with conventional therapies such as insulin or insulinotropic sulphonylureas, while useful in reducing hyperglycemia, may impose a higher risk of hypoglycemia. ${ }^{1}$ Glucagon-like peptide-1-(7-36) amide (GLP-1) is an incretin hormone derived from proglucagon, which is released from intestinal L-cells and stimulates insulin secretion in a glucose-dependent manner, insulin gene expression, and $\beta$-cell growth and differentiation. ${ }^{2}{ }^{3}$ Evidence that L-cells are themselves nutrient sensitive supports the idea that at least a component of oral

\section{Significance of this study}

What is already known about this subject?

- Although glucolipotoxicity of $\beta$-cell is a wellaccepted concept, it has not been known whether glucagon-like peptide-1-(7-36) amide (GLP-1) secretion and/or production would also be influenced by the glucolipotoxic conditions of L-cell in vitro and/ or in vivo.

What are the new findings?

- Glucolipotoxicity could be induced in vitro in human L-cell line and in vivo by prolonged glucose and/or lipid infusion into nondiabetic rats and was associated with the significantly decreased GLP-1 secretion and biosynthesis in L-cells.

- A negative effect of the glucolipotoxicity on GLP-1 secretion also affected $\beta$-cells.

- Glucolipotoxicity-induced decrease in GLP-1 secretion was prevented by cotreatment with insulin.

How might these results change the focus of research or clinical practice?

- It would lead to further studies on how to prevent glucolipotoxicity of $\beta$-cells and L-cells in vivo and on the pathophysiological implications during the development of type 2 diabetes as well.

glucose-stimulated GLP-1 release arises from the direct stimulation of L-cells by luminal sugars. ${ }^{4}$ However, GLP-1 is rapidly degraded by the action of the enzyme dipeptidyl peptidase- 4 (DPP-4). Therefore, DPP-4 inhibitors and longacting GLP-1 analogues are widely used to treat people with type 2 diabetes. ${ }^{5}$ The incretin-based therapies improve glycemic control with a low risk of hypoglycemia and can also have beneficial non-glycemic effects, such as the avoidance of weight gain, reduced blood pressure and improvements in $\beta$-cell function. ${ }^{6}$

Glucolipotoxicity might play an essential role in the $\beta$-cell decompensation during the development of obesity-associated type 2 diabetes, since the effect of postprandial and subsequently persistent hyperglycemia, added to the high levels of non-esterified fatty acids and triglycerides, could lead to $\beta$-cell exhaustion. The secretory machinery of intestinal L-cells shares similarities with that of pancreatic $\beta$-cells. ${ }^{78}$ Notably, studies have demonstrated that glucose-stimulated GLP-1 
secretion incorporates potassium $\left(\mathrm{K}_{\text {ATP }}\right)$ channel and voltage-dependent calcium channels. ${ }^{8}$ The precise mechanism by which macronutrients cause incretin hormone release is not fully understood, but direct interaction between the ingested nutrients and the L-cells may be the principal mechanism involved. It has been known from meta-analysis that GLP-1 secretion is not significantly decreased in patients with type 2 diabetes, ${ }^{9}$ and although glucolipotoxicity of $\beta$-cell is a well-accepted concept,${ }^{10} 11$ it has not been known whether GLP-1 secretion and/ or production is decreased in glucolipotoxic conditions of L-cells. Until now, insulin-secreting $\beta$-cells have been thought to be directly affected by glucolipotoxicity. ${ }^{12} 13$ If glucotoxicity and/or lipotoxicity develop in intestinal L-cells that secrete GLP-1, insulin secretion would also be decreased, and it becomes difficult to reduce hyperglycemia. However, in contrast, if the glucolipotoxicity of the $\beta$-cells may precede it, it may affect the GLP-1 secretion of the L-cell function, as insulin is a well-known GLP-1 secretagogue. ${ }^{14}$

In this study, we investigated whether glucolipotoxicity could be induced by exposure to high glucose and/ or fatty acids in L-cells. In vivo experiments were also conducted to investigate the changes of GLP-1, insulin, and C-peptide during prolonged hyperglycemia and/or lipid infusion. To the best of our knowledge, this is the first report on the mechanisms underlying glucolipotoxicityinduced GLP-1 secretory defects from both in vitro and in vivo experiments.

\section{MATERIALS AND METHODS \\ Cell culture}

Human NCI-H716 cells (ATCC, Manassas, Virginia. USA) were maintained in RPMI-1640 containing $10 \%$ fetal bovine serum (FBS) and $1 \%$ antibiotics in $5 \% \mathrm{CO}_{2}$ at $37^{\circ} \mathrm{C}$. The cells were grown in suspension, so dishes were coated with Matrigel (Becton Dickinson, Bedford, MA), as described previously. ${ }^{15}$ Rat pancreatic $\beta$-cell line, INS-1 cells, were cultured in RPMI-1640 medium containing $11 \mathrm{mM}$ glucose and supplemented with $10 \%$ FBS, $1 \mathrm{mM}$ sodium pyruvate, $10 \mathrm{mM}$ 2-[4-(2-hydroxyethyl) piperazin-1-yl] ethanesulfonic acid (HEPES) (pH 7.4), $2.05 \mathrm{mM}$ L-glutamine, and $50 \mu \mathrm{M} \beta$-mercaptoethanol, $100 \mathrm{U} / \mathrm{mL}$ penicillin, and $100 \mu \mathrm{g} / \mathrm{mL}$ streptomycin. Glucose was prepared and filter sterilized before use. Palmitate was dissolved in $50 \%$ ethanol and coupled to $5 \%$ fatty acidfree bovine serum albumin (BSA) at $37^{\circ} \mathrm{C}$ for 1 hour. All chemicals used in cell culture were obtained from SigmaAldrich (Sigma, St. Louis, Missouri, USA) unless otherwise indicated.

\section{Measurement of GLP-1 secretion}

To determine the responses to glucotoxic and lipotoxic conditions, the cells were exposed to media containing either five or $25 \mathrm{mM}$ glucose with or without $500 \mu \mathrm{M}$ palmitate for up to 72 hand incubated in Krebs-Ringer bicarbonate-HEPES buffer $(140 \mathrm{mM} / \mathrm{L} \mathrm{NaCl}, 3.6 \mathrm{mM} / \mathrm{L}$
$\mathrm{KCl}, 0.5 \mathrm{mM} / \mathrm{L} \mathrm{NaH}{ }_{2} \mathrm{PO}_{4}, 0.5 \mathrm{mM} / \mathrm{L} \mathrm{MgSO}, 1.5 \mathrm{mM} / \mathrm{L}$ $\mathrm{CaCl}_{2}, 2 \mathrm{mM} / \mathrm{L} \mathrm{NaHCO}_{3}, 10 \mathrm{mM} / \mathrm{L}$ HEPES) supplemented with $3.3 \mathrm{mM}$ glucose (basal glucose, BG) and $0.1 \%$ BSA at $37^{\circ} \mathrm{C}$ for $1 \mathrm{~h}$ under $95 \% \mathrm{O}_{2} / 5 \% \mathrm{CO}_{2}$ atmosphere for preincubation. The incubation of the cells was performed with Krebs-Ringer bicarbonate HEPES buffer (KRBH) containing 3.3 or $16.7 \mathrm{mM}$ glucose (high glucose, $\mathrm{HG}$ ) for 1 hour at $37^{\circ} \mathrm{C}$, and then the medium was collected for detection of total GLP-1 secretion using an enzyme immunoassay (Alpco diagnostics, Salem, NH).

\section{Western blot analysis}

Cells were lysed with radioimmunoprecipitation assay buffer (RIPA) buffer containing $150 \mathrm{mM} \mathrm{NaCl}, 20 \mathrm{mM}$ Tris, $0.1 \%$ SDS, $1 \%$ Triton X-100, 0.25\% Na-deoxycholate, $1 \mathrm{mM} \mathrm{Na} \mathrm{VO}_{4}, 50 \mathrm{mM} \mathrm{NaF}, 2 \mathrm{mM}$ EDTA and protease inhibitor cocktail (Sigma-Aldrich). Total protein concentration was determined by Bio-Rad DC protein assay, ${ }^{16}$ using BSA as a standard (Bio-Rad Laboratories, Hercules, California, USA). Protein was resolved on an sodium dodecyl sulphate polyacrylamide gel electrophoresis (SDS-PAGE), transferred to a polyvinylidene fluoride (PVDF) membrane, and probed with specific antibodies. The signaling was visualized with ECL Plus Western Blotting Detection System (GE Healthcare, Madison, Wisconsin, USA).

\section{Total RNA extraction and RT-PCR}

Total RNA was extracted by TRIZOL reagent (Invitrogen), and used to prepare cDNA using the Preamplification System of the SUPERSCRIPT First-strand Synthesis System (Invitrogen). The cDNA obtained was amplified directly by PCR.

\section{Apoptosis assay}

At 24,48 , and 72 hours, cell viability was assessed by 3-(4, 5-dimethylthiazol-2-yl)-2,5-diphenyltetrazolium bromide (MTT; Invitrogen, Carlsbad, California, USA) according to the manufacturer's instructions.

\section{Biochemical analyses}

Glucose uptake (BioVision, Milpitas, California, USA), nicotinamide-adenine dinucleotide phosphate (NADPH) (BioVision), triglycerides (TG) (Asan Pharm., Seoul, South Korea), ATP (Promega, Madison, Wisconsin, USA), cAMP (Enzo Life Sciences, Farmingdale, New York, USA), ceramide (MyBioSource, San Diego, California, USA), Complex I activity (BioVision), and insulin (Mercodia, Uppsala, Sweden) were measured according to the manufacturer's directions, respectively.

\section{Measurement of intracellular reactive oxygen species (ROS)} levels and antioxidant enzymes

The quantification of intracellular ROS levels was carried out using the fluorescent probe, 2,7-dichlorofluorescein diacetate (DCFH-DA) (Molecular Probes, Eugene, Oregon, USA) and the carboxy-DCF fluorescence in the cell lysates was measured using a multimode microplate reader (Bio-Rad, Hercules, California, USA) and 
excitation and emission wavelengths of 488 and $530 \mathrm{~nm}$, respectively. Superoxide dismutase (SOD), catalase, and glutathione (BioVision) were determined according to the manufacturer's directions.

\section{Animal experiments}

This study was reviewed and approved by the Institutional Animal Care and Use Committee of the Samsung Biomedical Research Institute (SBRI No. OTC1190171, Seoul, South Korea). SBRI is an Association for Assessment and Accreditation of Laboratory Animal Care International accredited facility and abide by the Institute of Laboratory Animal Resources guide. Male Sprague Dawley rats (OrientBio, Seoul, South Korea) weighing 250-300g were housed under controlled temperature $21^{\circ} \mathrm{C}$ and 12 hours light/dark cycle with ad libitum access to water and standard laboratory chow. Under general anesthesia with isoflurane and nitrous oxide, indwelling catheters were inserted into the left carotid artery and right jugular vein. The catheters were tunneled subcutaneously and exteriorized at the base of the neck. ${ }^{17}$ The animals were recovered for 7 days after surgery. Catheter patency was maintained with 50 units/ $\mathrm{mL}$ heparin in $0.9 \%$ saline (Dai Han Pharm., Ansan, South Korea). The animals were randomized into four groups, receiving either $0.9 \%$ saline, $50 \%$ glucose (D50, Dai Han Pharm), 20\% SMOFlipid (IL20, Fresenius Kabi $\mathrm{AB}$, Uppsala, Sweden) with heparin (20 units $/ \mathrm{mL}$ ), or glucose plus SMOFlipid with heparin. The infusion profile was controlled by a Harvard infusion pump (Pump 33; Harvard Apparatus Canada, Saint-Laurent, QC, Canada) capable of independently operating two syringes simultaneously. Glucose was infused at $2 \mathrm{~mL} /$ hour and SMOFlipid at $1 \mathrm{~mL} /$ hour for 6 hours. During the infusion, all animals had ad libitum access to food and water, and plasma glucose levels were measured every 2 hours during the infusion period.

\section{Mixed meal tolerance test}

After overnight fasting, a mixed meal load $(3.7 \mathrm{kcal}$, $2.5 \mathrm{~mL} / 300 \mathrm{~g}$ body weight) was administered orally. The liquid mixed meal consisted of a commercial product (1 can: $300 \mathrm{kcal} / 200 \mathrm{~mL}$ : $12 \%$ carbohydrate, $24 \%$ protein, 22\% fat, Mediwell Diabetic Meal; Maeil Dairies, Seoul, South Korea). Blood was drawn by eye bleed at 0,30 , 60,90 , and $120 \mathrm{~min}$ after the meal administration for measurement of glucose (AccuCheck II; Roche, Indianapolis, Indy, USA), and plasma samples were stored at $-20^{\circ} \mathrm{C}$, until further assays. GLP-1 (Alpco diagnostics), insulin and C-peptide (Mercodia) levels were measured using the corresponding ELISA kits. The insulin sensitivity (Homeostasis model assessment of insulin resistance $($ HOMA-IR $)=$ fasting glucose $\times$ fasting insulin $\div 22.5)$ and $\beta$-cell function index (Homeostasis model assessment of $\beta$-cell function (HOMA- $\beta)=20 \times$ fasting insulin $(\mu \mathrm{U} / \mathrm{mL}) /($ fasting glucose $(\mathrm{mM} / \mathrm{L})-3.5))$ were also calculated.

\section{Statistical analyses}

Results were expressed as the mean $\pm \mathrm{SD}$ and were analyzed using SPSS V.10.0 software (SPSS, Chicago, Illinois, USA). Data were validated by analysis of variance, and a $\mathrm{p}<0.05$ as indicated by Duncan's multiple range test was considered to indicate a statistically significant difference.

\section{RESULTS}

\section{Chronic glucolipotoxicity reduced GLP-1 secretion}

In the presence of BG, GLP-1 secretion was significantly increased under $5 \mathrm{mM} \mathrm{G}+500 \mu \mathrm{M} \mathrm{P}(5 \mathrm{mM} \mathrm{GP})$, and glucolipotoxicity conditions $(25 \mathrm{mM}$ glucose $+500 \mu \mathrm{M}$ palmitate, $25 \mathrm{mM} \mathrm{GP})$, compared with under $5 \mathrm{mM}$ glucose ( $5 \mathrm{mM} \mathrm{G}$ ). The $25 \mathrm{mM}$ glucose $(25 \mathrm{mM} \mathrm{G})$ significantly increased GLP-1 secretion at 24 and 48 hours, compared with these groups. However, GLP-1 secretion was significantly reduced in the chronic hyperglycemia and glucolipotoxicity conditions at 72 hours. In the presence of HG, GLP-1 secretion was significantly increased under $5 \mathrm{mM} \mathrm{GP}$ and $25 \mathrm{mM} \mathrm{G}$, than under $5 \mathrm{mM} \mathrm{G}$ at 24 , 48 , and 72 hours; however, it was considerably reduced under chronic glucolipotoxicity conditions at 72 hours (figure 1A). Western blots revealed significant inhibition of cAMP-response element-binding protein (CREB) phosphorylation, and GSK-3 $\beta$ activity as reflected by the decreased phosphorylation of GSK- $3 \beta$ in chronic glucolipotoxic condition, and downregulation of nuclear $\beta$-catenin expression and transcription factor 7-like 2 (TCF7L2) as well as GLP-1 (figure 1B), which are compatible with the decreased WNT/ $\beta$-catenin signaling that is the critical mechanism of GLP-1 biosynthesis and could lead to decreased GLP-1 production and secretion at 72 hours. Chronic glucolipotoxicity conditions significantly decreased the expression of proglucagon in NCIH716 cells compared with other groups (figure 1C).

\section{Chronic glucolipotoxicity impaired glucose and fatty acid metabolism and $\mathrm{K}_{\mathrm{ATP}}$ and Ca channel}

There were no significant differences in cell proliferation between groups (figure 2A). The expressions of sodiumglucose cotransporter 1 (SGLT1) and glucose transporter 2 (GLUT2) were significantly increased in $25 \mathrm{mM} \mathrm{G}$, compared with $5 \mathrm{mM} \mathrm{G}$, but were significantly decreased in $25 \mathrm{mM}$ GP compared with $25 \mathrm{mM} \mathrm{G}$ (figure 2B). In line with these results, glucose uptake under $25 \mathrm{mM}$ GP significantly decreased, compared with under $25 \mathrm{mM} \mathrm{G}$ (figure 2C). Consistent with these data, NADPH levels were significantly decreased in $25 \mathrm{mM}$ GP, compared with $25 \mathrm{mM} \mathrm{G}$ confirming a dysfunction in glucose metabolism (figure 2D). Protein levels of the fatty acid transporter, CD36, were significantly increased in lipotoxic condition (5mM GP) and glucolipotoxic condition (figure 2E). Further, we also found fat metabolism to be impaired under chronic glucolipotoxic condition as seen from the 1.5-fold increase in triglyceride levels (figure 2F). PPAR $\alpha$ level was significantly decreased in chronic glucolipotoxic condition than under $5 \mathrm{mM}$ GP (figure 2E); and 


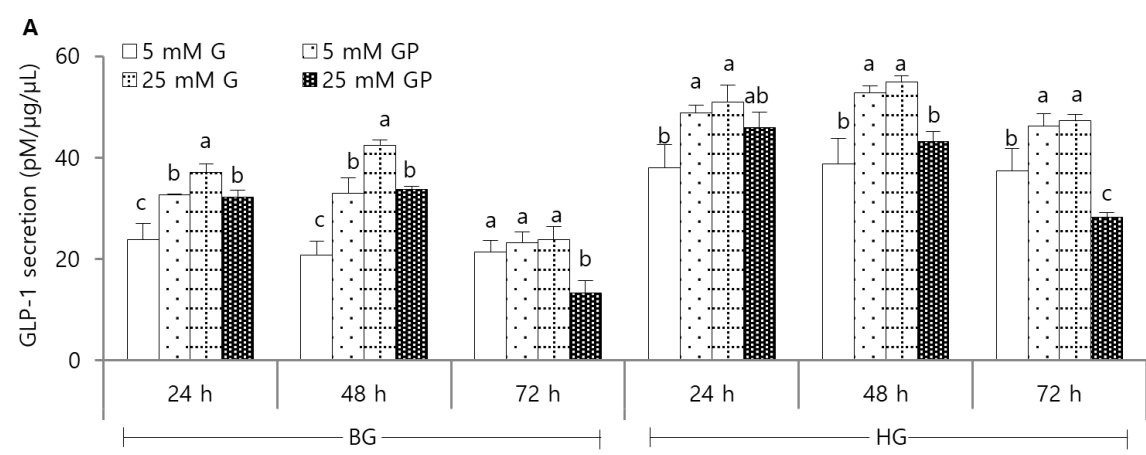

B
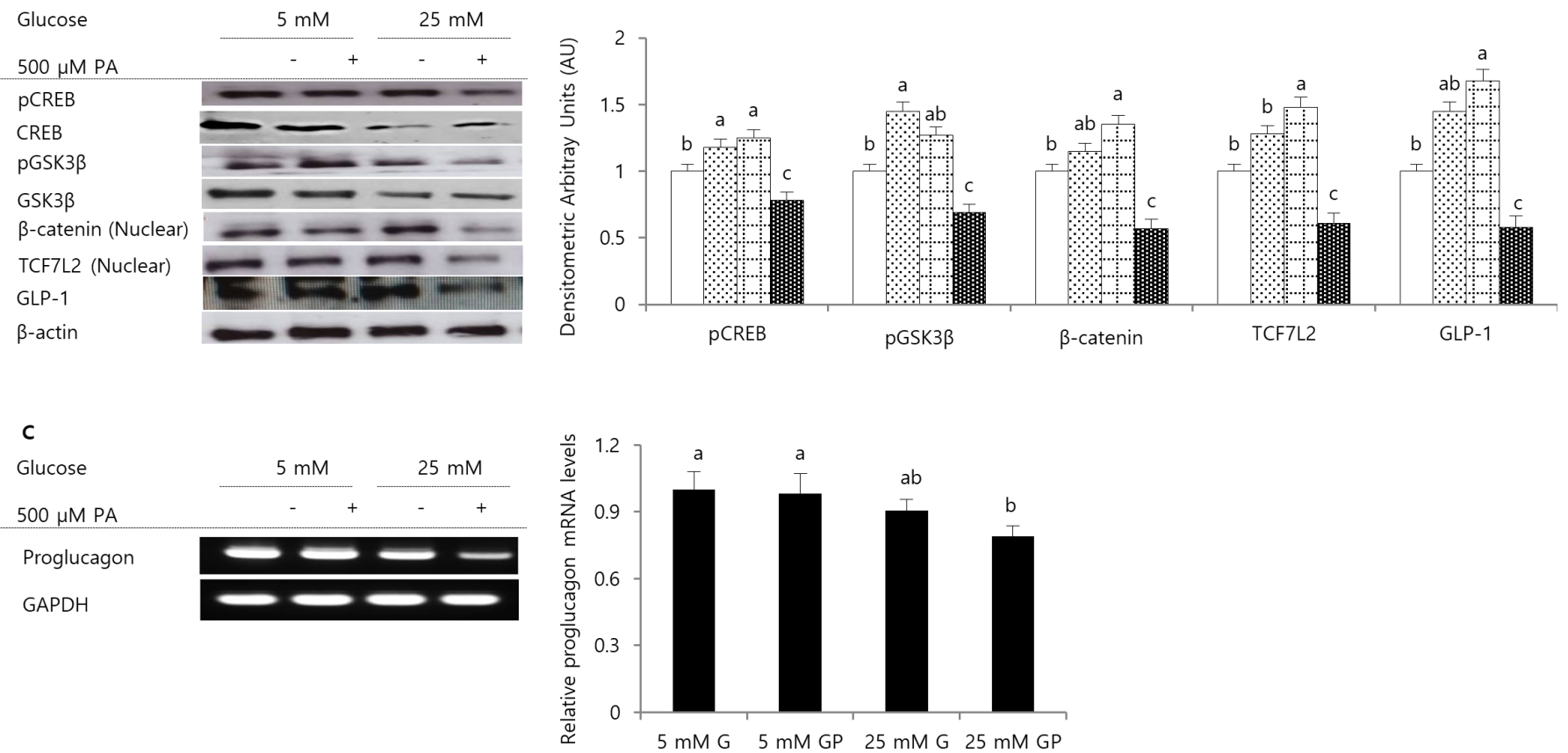

Figure 1 Glucolipotoxicity reduce GLP-1 secretion. NCl-H716 cells were cultured under 5 or $25 \mathrm{mM}$ glucose with or without $500 \mu \mathrm{M}$ palmitate for up to 72 hours. (A) After 72 hours stimulation, the cells were treated with BG or HG for 2 hours, and secreted GLP-1 was measured. (B) Protein levels of pCREB, pGSK3 $\beta$, $\beta$-catenin, TCF7L2, and GLP-1 were measured by western blotting. (C) The relative mRNA expression level of proglucagon, a precursor of GLP-1, was determined in $\mathrm{NCl}-\mathrm{H} 716$ cells that were cultured for 72 hours. $5 \mathrm{mM} \mathrm{G}=5 \mathrm{mM}$ glucose, $5 \mathrm{mM} \mathrm{GP}=5 \mathrm{mM}$ glucose $+500 \mu \mathrm{M}$ palmitate, $25 \mathrm{mM}$ $\mathrm{G}=25 \mathrm{mM}$ glucose, $25 \mathrm{mM}$ GP $=25 \mathrm{mM}$ glucose $+500 \mu \mathrm{M}$ palmitate. Data are presented as the mean $\pm S D(n=5)$. Values with different superscript letters are significantly different at $p<0.05$, compared with the control. $B G$, basal glucose; CREB, cAMPresponseelement-bindingprotein; GAPDH, glyceraldehyde-phosphate-dehydrogenase; GLP-1, glucagon-like peptide-1-(7-36) amide; HG, high glucose; TCF7L2, transcription factor 7-like 2.

cellular ATP level was also significantly reduced in chronic glucolipotoxic conditions than under $25 \mathrm{mM} \mathrm{G}$ (figure $2 \mathrm{G}$ ).

Chronic glucolipotoxic conditions impaired sulfonylurea receptor 1 (SUR1), Kir6.2 expressions (figure 2H), and cAMP (figure 2I) level. $\mathrm{Ca}^{2+} /$ calmodulin-dependent protein kinase II (CaMKII) phosphorylation and protein kinase A (PKA) expression were significantly increased in $25 \mathrm{mM} \mathrm{G}$ compared with $5 \mathrm{mM} \mathrm{G}$, which, however, were significantly suppressed under chronic glucolipotoxic conditions (figure 2J).

\section{Chronic glucolipotoxicity induced ROS production and reduced antioxidant capacity but reversible chronic glucolipotoxicity by recovery insulin in NCI-H716 cells}

As shown in figure $3 \mathrm{~A}$, chronic glucolipotoxic conditions were associated with significantly increased ROS production.
Ceramide concentrations were increased by chronic glucolipotoxicity, but there was no statistically significant difference between groups (figure 3B). Interestingly, uncoupling protein-2 (UCP2) levels were significantly increased in chronic glucolipotoxic conditions (figure 3C). The activity of reduced nicotinamide adenine dinucleotide (NADH)dehydrogenase, Complex I was increased by $23 \%$ in chronic glucolipotoxic condition, than under $5 \mathrm{mM} \mathrm{G}$ (figure 3D). Cell permeable $\mathrm{SOD}$, which metabolizes $\cdot \mathrm{O}_{2}^{-}$into $\mathrm{H}_{2} \mathrm{O}_{2}$ showed no difference among groups (figure $3 \mathrm{E}$ ). However, catalase activity (figure $3 \mathrm{~F}$ ) and glutathione content (figure 3G) were significantly decreased in chronic glucolipotoxic condition, compared with under $5 \mathrm{mM} \mathrm{G}$.

Meanwhile, there was no significant difference in GLP-1 secretion after 24 hours recovery time from glucolipotoxicity 


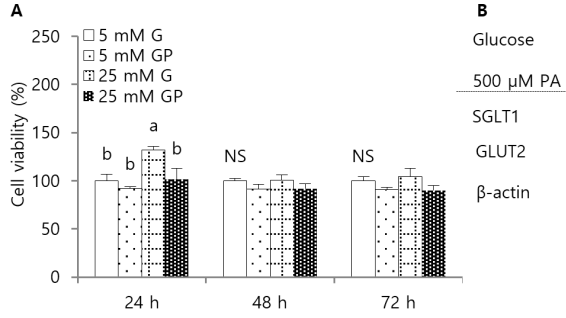

D
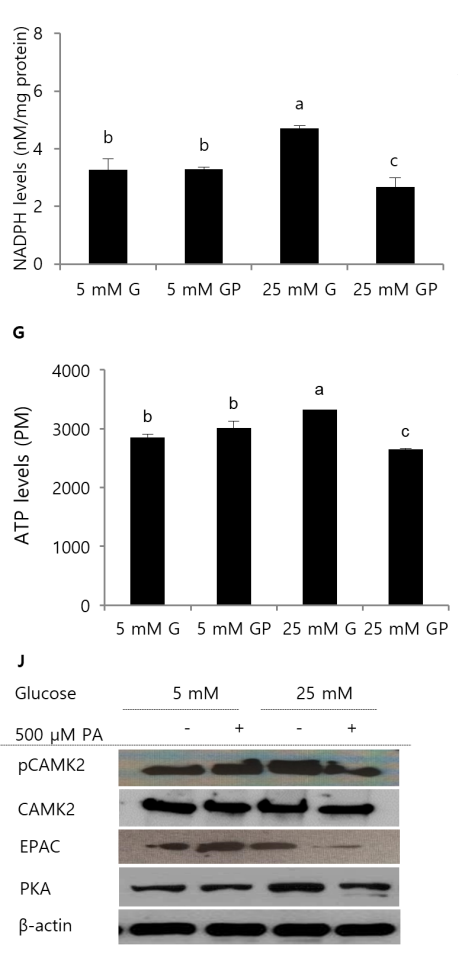

H
E

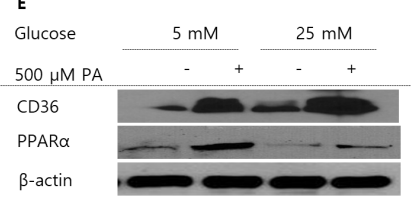

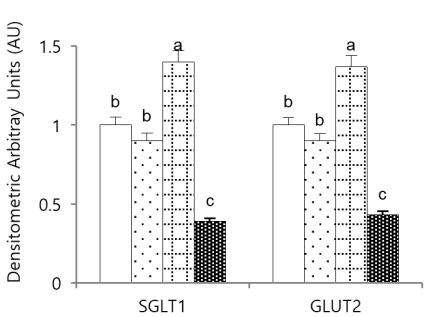
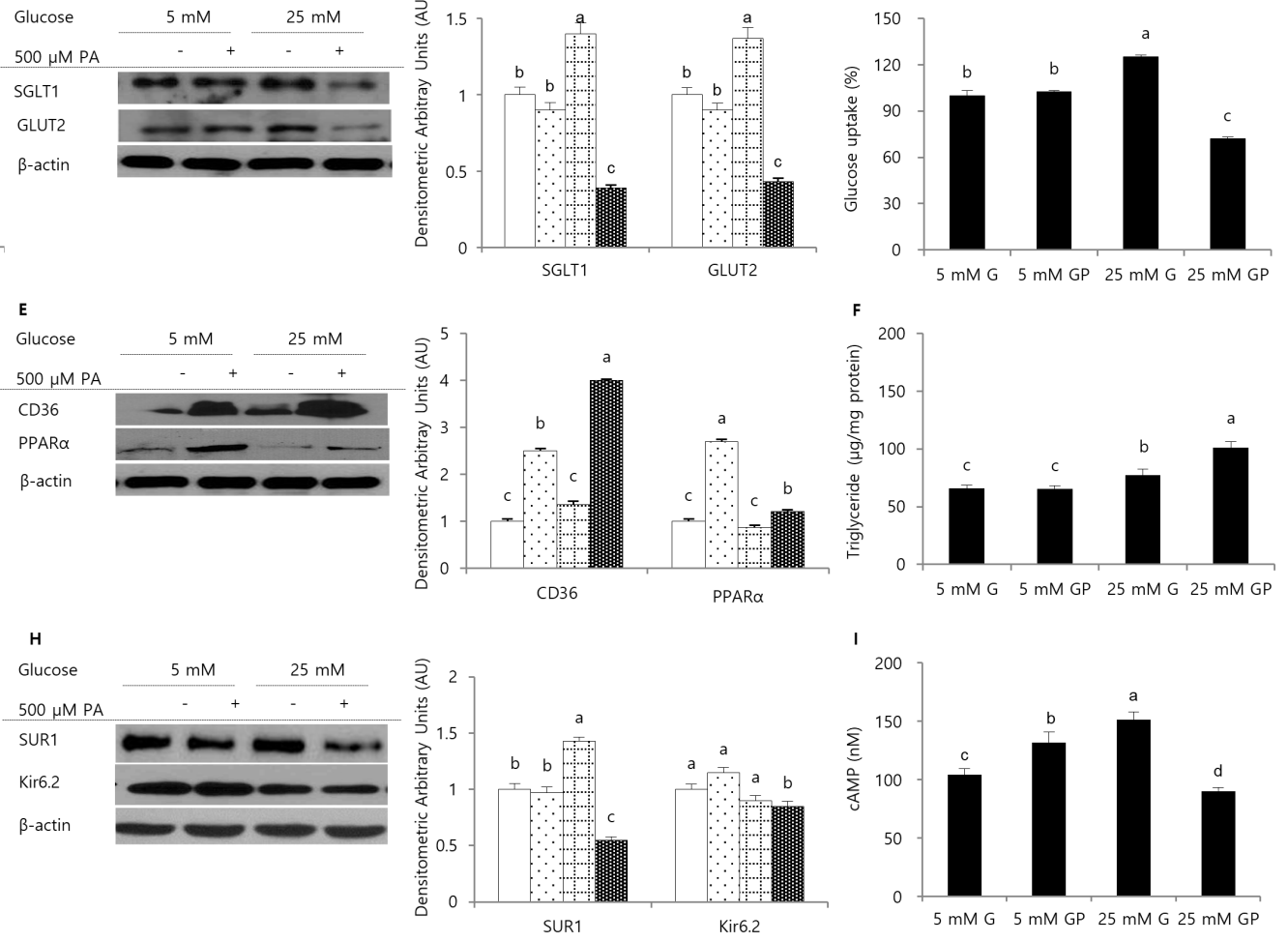

Figure 2 Chronic glucolipotoxicity impairs glucose and free fatty acid metabolism and $\mathrm{K}_{\text {ATP }}$ and Ca channels NCl-H716 cells were cultured under 5 or $25 \mathrm{mM}$ glucose with or without $500 \mu \mathrm{M}$ palmitate for up to 72 hours. (A) MTT assay for measuring cellular toxicity at various time points. (B) Protein levels of SGLT1 and GLUT2 were measured by western blotting. (C) Glucose uptake was measured using 2-NBDG, a non-metabolized fluorescent analog. (D) Cellular NADPH levels were measured. (E) Protein levels of CD36 and PPAR $\alpha$ were measured by western blotting. (F) Cellular triglyceride levels and (G) ATP levels were estimated. (H) Protein levels of SUR1 and Kir6.2 were measured by western blotting. (I) cAMP was measured. (J) Protein levels of pCAMK2, EPAC, and PKA were measured by western blotting. $5 \mathrm{mM} \mathrm{G}=5 \mathrm{mM}$ glucose, $5 \mathrm{mM} \mathrm{GP}=5 \mathrm{mM}$ glucose $+500 \mu \mathrm{M}$ palmitate, $25 \mathrm{mM} \mathrm{G}=25 \mathrm{mM}$ glucose, $25 \mathrm{mM} \mathrm{GP}=25 \mathrm{mM}$ glucose $+500 \mu \mathrm{M}$ palmitate. Data are presented as the mean $\pm \mathrm{SD}$ $(n=5)$. Values with different superscript letters are significantly different at $p<0.05$, compared with the control. EPAC, exchange proteins directly activated by CAMP; GLUT2, glucose transporter 2; MTT, 3-(4,5-dimethylthiazol-2-yl)-2,5-diphenyltetrazolium bromide; NADPH, nicotinamide-adenine dinucleotide phosphate; NBDG, 6-deoxy-6[(7-nitro-2,1,3-benzoxadiazol-4-yl) amino]D-glucose; NS, not significant; PKA, protein kinase A; SGLT1, sodium-glucose cotransporter 1; SUR1, sulfonylurea receptor 1.

(figure 3H). A decreased GLP-1 secretion in glucolipotoxicity conditions was reversible by reverting to RPMI-1640 (growth media) for over 48 and 72 hours, respectively (figure 3I,J). Moreover, the decreased GLP-1 secretion in chronic glucolipotoxicity conditions was prevented after the cotreatment with $100 \mathrm{nM}$ insulin (figure 3K) or NCI-H716 and INS-1 coculture for 72 hours (figure 3L).

\section{Chronic glucolipotoxicity reduced insulin secretion in INS-1 cells}

INS-1 cell viability was significantly decreased from 24 hours in glucolipotoxicity condition (figure 4A). Decreased insulin secretion was reversible by reverting to RPMI-1640 (growth media) after 24 hours (figure $4 \mathrm{~B}$ ). However, there was no such effect after 48 and 72 hours (figure 4C,D). Furthermore, insulin contents were significantly reduced by 72 hours, compared with 24 hours, except under $5 \mathrm{mM} \mathrm{G}$ (figure $4 \mathrm{E}$ ). Decreased insulin secretion was prevented after the cotreatment with $100 \mu \mathrm{M} \mathrm{Ex}-4$ for 72 hours (figure $4 \mathrm{~F}$ ). INS-1 and NCI-H716 cocultured for 72 hours in glucolipotoxic conditions prevented the decrease in insulin secretion as well, and the preventive effect was higher than that of Ex-4 only treatment (figure 4G).

\section{Effects on glycemia, pancreatic $\beta$-cell function, and incretin levels after mixed meal load in rats}

Rats were divided into four groups, and received saline (NS), 50\% dextrose (D50), 20\% SMOFlipid (IL20), or 

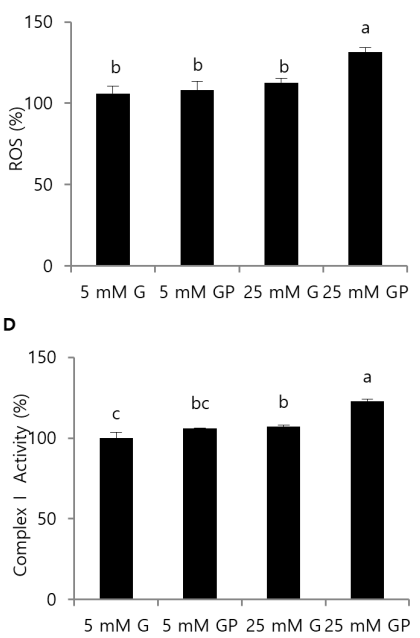

H
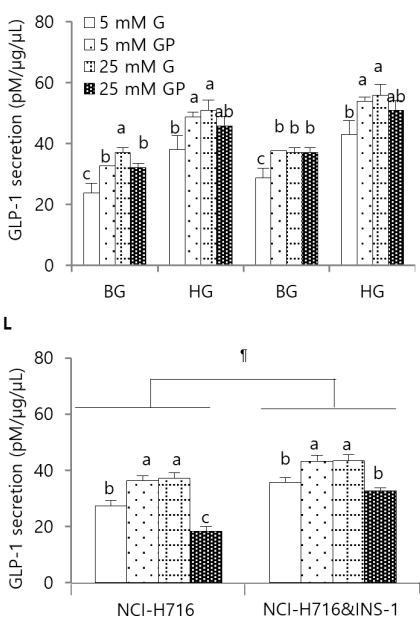

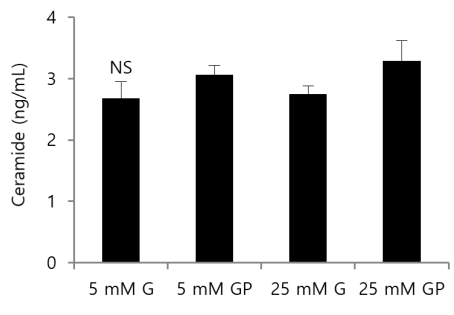

E
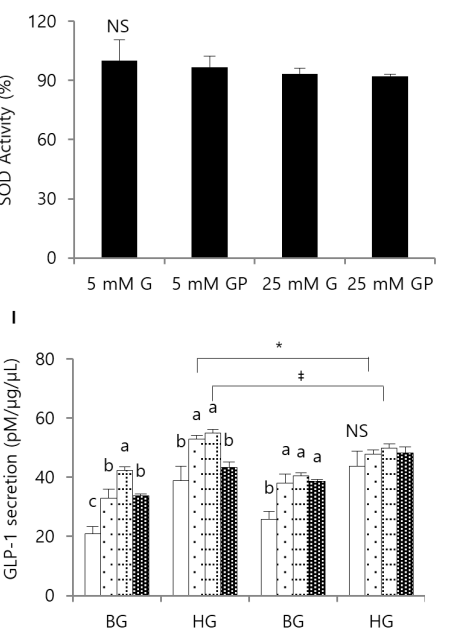
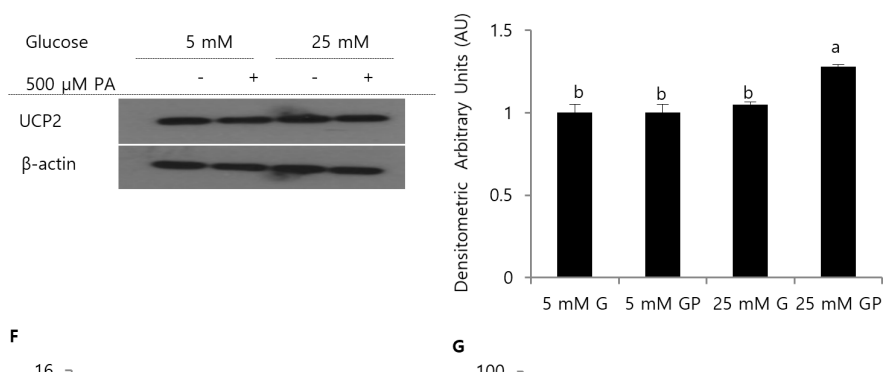

G
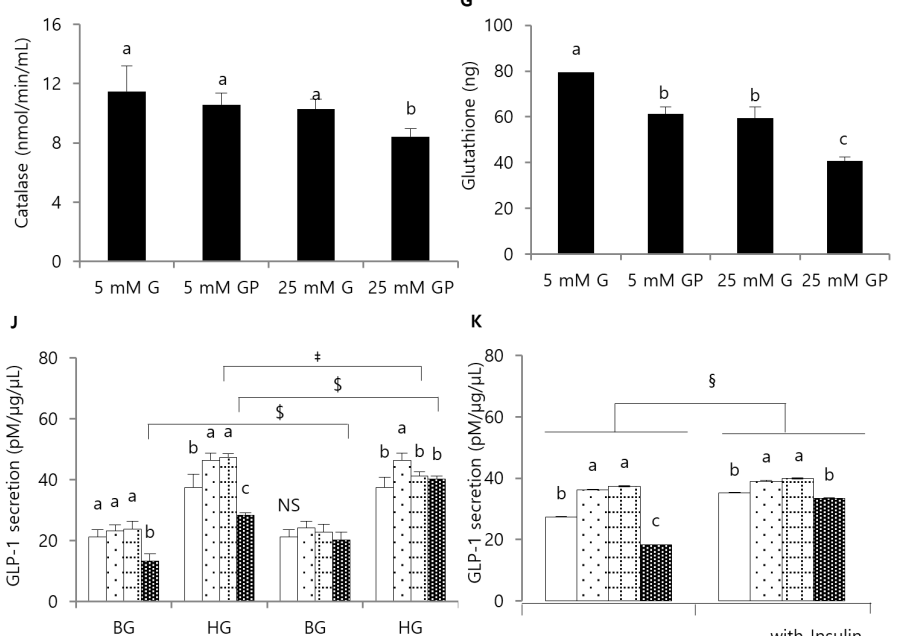

with Insulin

Figure 3 Chronic glucolipotoxicity induced ROS production and reduced antioxidant capacity but reversible chronic glucolipotoxicity by recovery insulin in $\mathrm{NCl}-\mathrm{H} 716$ cells. $\mathrm{NCl}-\mathrm{H} 716$ cells were cultured under 5 or $25 \mathrm{mM}$ glucose with or without $500 \mu \mathrm{M}$ palmitate for up to 72 hours. (A) ROS production was measured using carboxy-H $\mathrm{H}_{2}$ DFFDA, a fluorescent analog. (B) Ceramide contents were measured. (C) Protein levels of UCP2 were measured by western blotting. (D) Complex I activity was measured. Antioxidant enzymes of (E) SOD, $(F)$ catalase, and $(G)$ glutathione were determined. $\mathrm{NCl}-\mathrm{H} 716$ cells were cultured under 5 or $25 \mathrm{mM}$ glucose with or without $500 \mu \mathrm{M}$ palmitate for up to 72 hours, and then GLP-1 secretion was measured. (H) Cells were incubated for 24 hours in glucolipotoxicity, and then replaced with RPMI-1640 media for 24 hours. (I) Cells were incubated for 48 hours in glucolipotoxicity and then replaced with RPMI-1640 media for 48 hours. (J) Cells were incubated for 72 hours in glucolipotoxicity and then replaced with RPMI-1640 media for 72 hours. (K) Cells were incubated for 72 hours in glucolipotoxicity with $100 \mathrm{nM}$ insulin. (L) NCl-H716 and INS-1 cells were cocultured for 72 hours in glucolipotoxicity. $5 \mathrm{mM}$ $\mathrm{G}=5 \mathrm{mM}$ glucose, $5 \mathrm{mM} \mathrm{GP}=5 \mathrm{mM}$ glucose $+500 \mu \mathrm{M}$ palmitate, $25 \mathrm{mM} \mathrm{G}=25 \mathrm{mM}$ glucose, $25 \mathrm{mM}$ GP= $25 \mathrm{mM}$ glucose $+500 \mu \mathrm{M}$ palmitate. Data are presented as the mean $\pm S D(n=5)$. Values with different superscript letters are significantly different at $\mathrm{p}<0.05$ compared with the control. ${ }^{*} \mathrm{P}<0.05$ for comparison of incubated $5 \mathrm{mM}$ GP vs replaced with RPMl- 1640 media. $¥ \mathrm{P}<0.05$ for comparison of incubated $25 \mathrm{mM}$ G vs replaced with RPMI- 1640 media. $\$ \mathrm{P}<0.05$ for comparison of incubated $25 \mathrm{mM}$ GP vs replaced with $\mathrm{RPMl}-1640$ media. $\$ \mathrm{P}<0.05$ for comparison of without Insulin vs Insulin. $\mathrm{IP}<0.05$ for comparison of $\mathrm{NCl}-\mathrm{H} 716 \mathrm{vs}$ $\mathrm{NCl}-\mathrm{H} 716$ and INS-1 cells cocultured. BG, basal glucose; GLP-1, glucagon-like peptide-1-(7-36) amide; HG, high glucose; NS, not significant; ROS, reactive oxygen species; SOD, superoxide dismutase; UCP2, uncoupling protein-2.

$50 \%$ dextrose+20\% SMOFlipid (Combination) for 6 hours, respectively (figure 5A). The infusions of NS and IL20 did not result in any significant change in blood glucose from baseline. The administration of D50 and Combination resulted in significant rises in blood glucose from baseline by $171 \%$ and $99 \%$ at 6 hours, respectively. Area under the curve (AUC) of the Combination was significantly decreased, compared with that of D50 (figure 5B). After recovery time for 16hours, fasting glucose levels of the D50 and
Combination group were still significantly higher than those of NS and IL20. AUC of the Combination was significantly increased, compared with that of NS (figure 5C). During mixed meal load, insulin (figure 5D), GLP-1 (figure 5E), and C-peptide (figure 5F) levels of D50, IL20, and Combination were significantly decreased, compared with those of NS. AUCs were decreased in D50, IL20, and Combination group compared with that of NS, but there was no statistically significant difference between groups (figure 5D-F). 

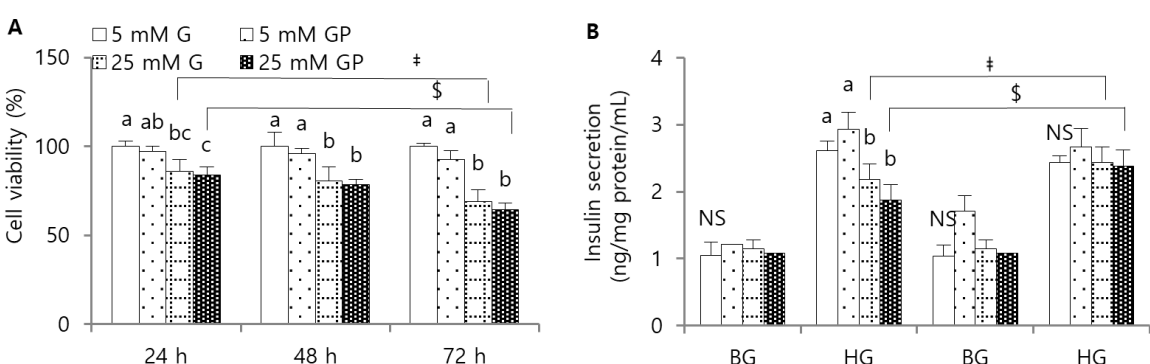

$\mathbf{E}$

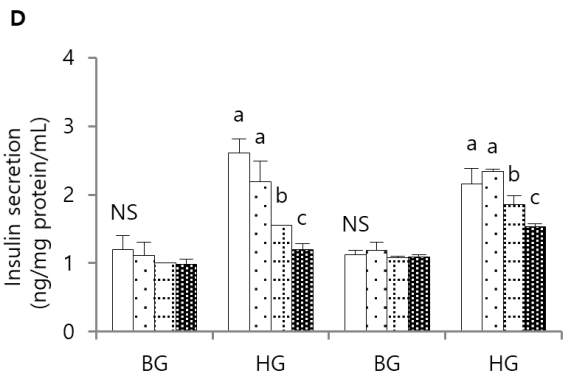

E

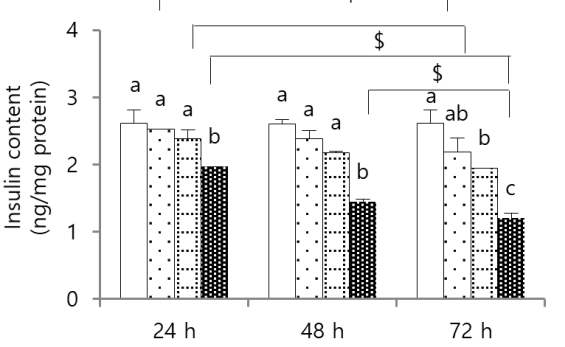

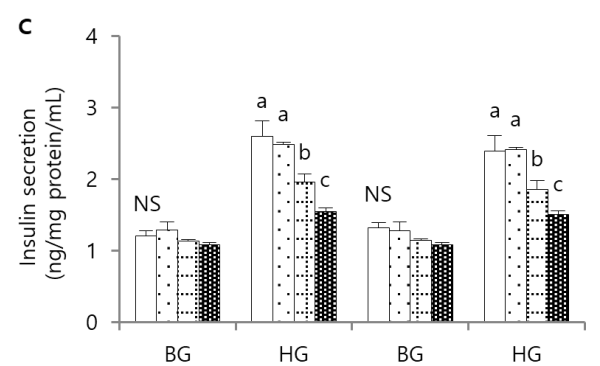

$\mathbf{F}$

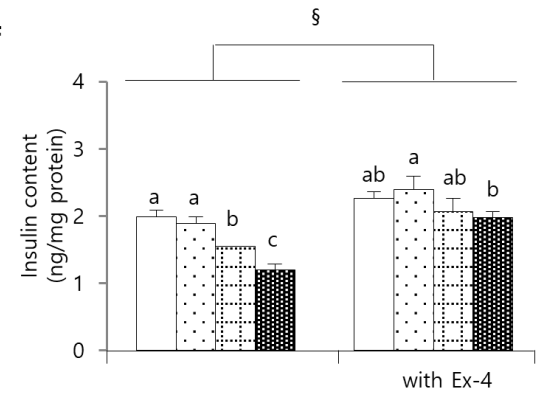

G

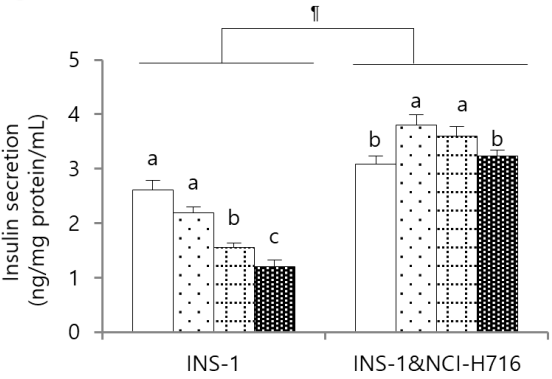

Figure 4 Reversible chronic glucolipotoxicity by recovery Ex-4 cotreatment in INS-1 cells. INS-1 cells were cultured under five or $25 \mathrm{mM}$ glucose with or without $500 \mu \mathrm{M}$ palmitate for up to 72 hours, and then insulin secretion was measured. (A) MTT assay for measuring cellular toxicity at various time points. (B) Cells were incubated for 24 hours in glucolipotoxicity and then replaced with RPMI-1640 media for 24 hours. (C) Cells were incubated for 48 hours in glucolipotoxicity and then replaced with RPMI-1640 media for 48 hours. (D) Cells were incubated for 72 hours in glucolipotoxicity and then replaced with RPMI1640 media for 72 hours. (E) Cells were incubated for 72 hours in glucolipotoxicity, and then insulin contents was measured. (F) Cells were incubated for 72 hours in glucolipotoxicity with $100 \mu \mathrm{M}$ Ex-4. (G) INS-1 and NCl-H716 cells were cocultured for 72 hours in glucolipotoxicity. $5 \mathrm{mM} \mathrm{G}=5 \mathrm{mM}$ glucose, $5 \mathrm{mM} \mathrm{GP}=5 \mathrm{mM}$ glucose $+500 \mu \mathrm{M}$ palmitate, $25 \mathrm{mM} \mathrm{G}=25 \mathrm{mM}$ glucose, $25 \mathrm{mM}$ GP $=25 \mathrm{mM}$ glucose $+500 \mu \mathrm{M}$ palmitate. Data are presented as the mean $\pm S D(n=5)$. Values with different superscript letters are significantly different at $\mathrm{p}<0.05$ compared with the control. ${ }^{*} \mathrm{P}<0.05$ for comparison of incubated $5 \mathrm{mM}$ GP vs replaced with RPMl- 1640 media. $\ddagger \mathrm{P}<0.05$ for comparison of incubated $25 \mathrm{mM} \mathrm{G}$ vs replaced with RPMl- 1640 media. $\$ \mathrm{P}<0.05$ for comparison of incubated $25 \mathrm{mM}$ GP vs replaced with RPMl-1640 media. $\S \mathrm{P}<0.05$ for comparison of without Ex-4 vs with Ex-4. IP $<0.05$ for comparison of INS-1 vs INS-1 and NCl-H716 cells cocultured. BG, basal glucose; HG, high glucose; MTT, 3-(4,5-dimethylthiazol-2-yl)-2,5-diphenyltetrazolium bromide; NS, not significant.

HOMA-IR was increased in D50, IL20, and Combination group compared with that of NS, but there was no statistically significant difference between groups (figure $5 \mathrm{G}$ ).

HOMA- $\beta$ was significantly decreased by $32,24 \%$, and $58 \%$ in D50, IL20, and Combination group (figure $5 \mathrm{H}$ ). The considerable decreases in the phosphorylated form of GSK-3 $\beta$, as well as $\beta$-catenin, TCF7L2, GLP-1, and proglucagon mRNA levels were noticed in D50, IL20, and Combination, compared with those of NS (figure 5I,J).

\section{DISCUSSION}

GLP-1, an incretin hormone derived from the transcription of the proglucagon gene, is released from the intestinal endocrine L-cells in response to nutritional stimuli. ${ }^{3}$
To investigate the effects of chronic glucolipotoxicity on GLP-1 secretion, we generated glucolipotoxic conditions in human origin NCI-H716 enteroendocrine cells using either 5 or $25 \mathrm{mM}$ glucose with or without $500 \mu \mathrm{M}$ palmitate for 72 hours (chronic glucolipotoxic conditions that mimic diabetic pathology). ${ }^{18}$ For in vivo study, we have established a chronic nutrient infusion model in the rat. In our experiments, the glucose and lipids were administered into the vascular spaces, and the lipids, after lipolysis in the intestinal capillaries, could be taken up by the L-cells. The glucose in the vascular spaces could not be taken up by the SGLT1 in the luminal surfaces in the intestinal L-cells; however, it could potentially be taken up by the GLUT2 in the basal surfaces of the intestinal 
A

Saline (NS),

$50 \%$ dextrose (D50)

$20 \%$ SMOFlipid (IL20),

$50 \%$ dextrose $+20 \%$ SMOFlipid (Combination) $(2 \mathrm{~mL} / \mathrm{h})$
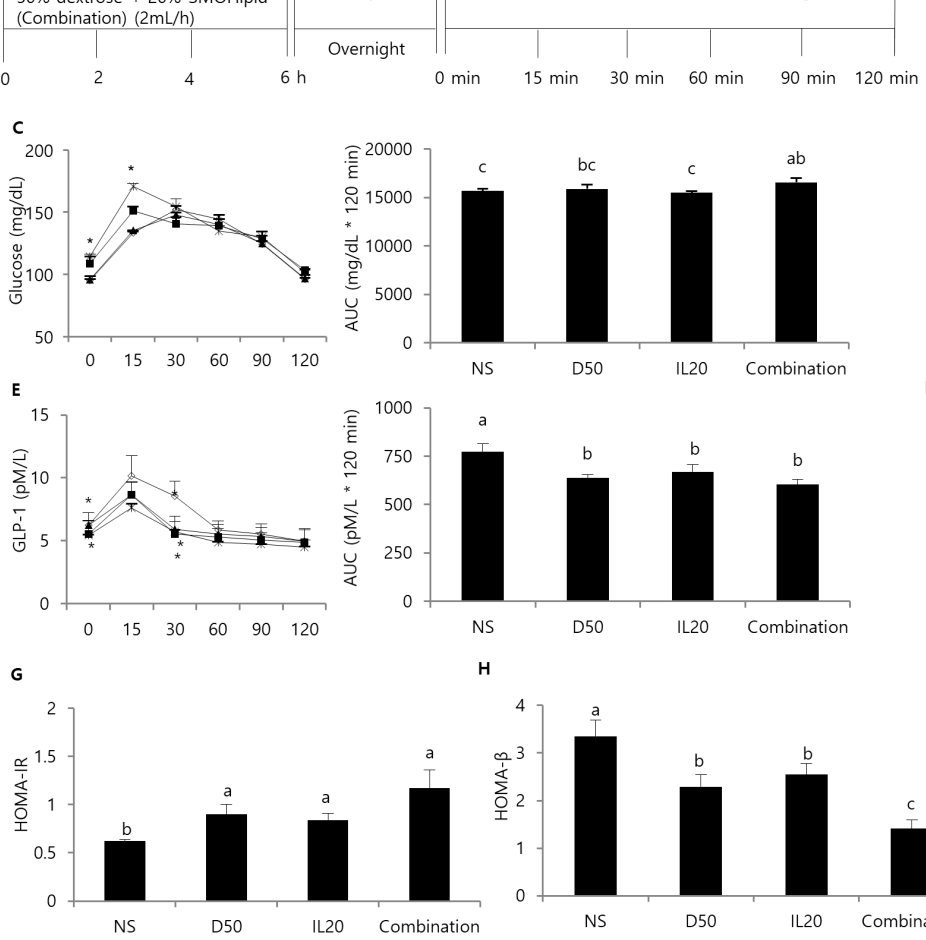

$\mathrm{H}$
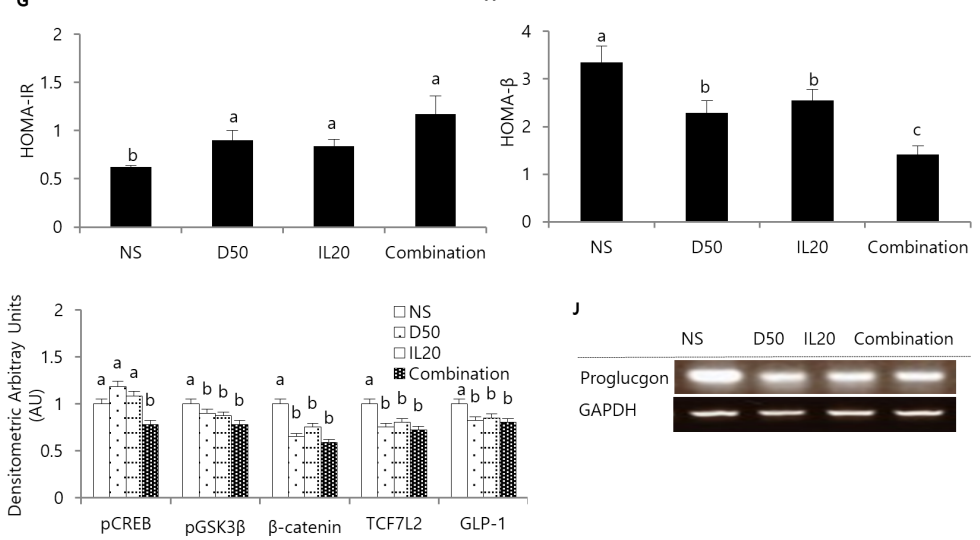
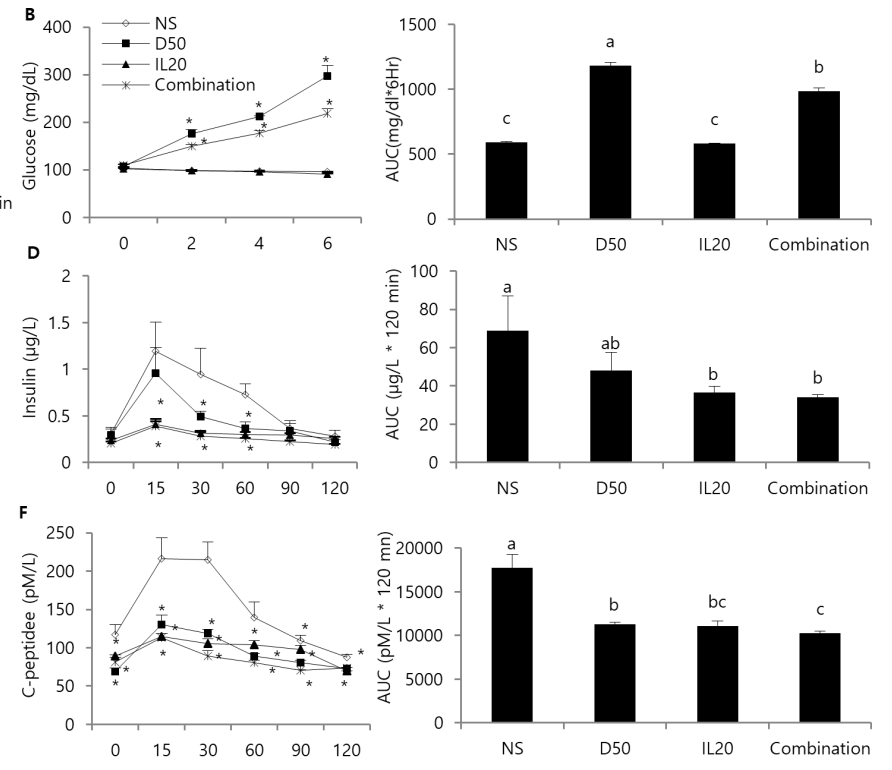

।

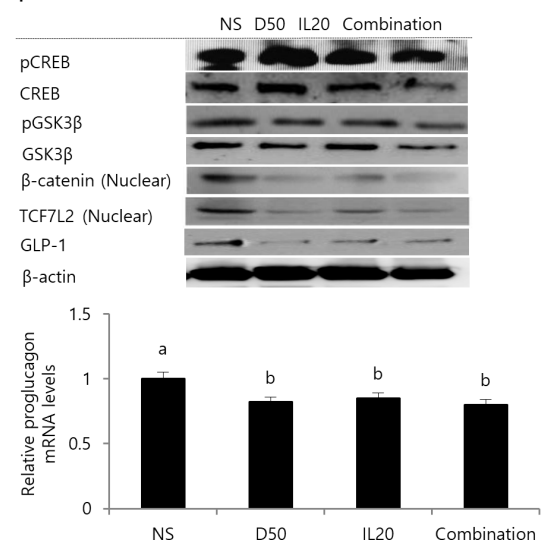

Effects on glycemic control, pancreatic $\beta$-cell function, and incretin levels after mixed meal load in rats. SpragueDawley rats were treated with saline (NS) and 50\% dextrose (D50\%) and 20\% SMOFlipid (IL20\%) or 50\% dextrose+20\% SMOFlipid (combination) for 6 hours. Rats were fasted for overnight and then orally administered mixed meals. Each level was measured at the indicated time points. (A) Experimental scheme. (B) Serum levels of glucose were measured for 6 hours during infusion of saline and $50 \%$ dextrose and $20 \%$ SMOFlipid or combination and AUC of glucose. (C) Glucose, (D) insulin, (E) GLP1, and (F) C-peptide were measured for 120 min. (G) HOMA-IR and (H) HOMA- $\beta$ were calculated. (I) Protein levels of pCREB, pGSK3 $\beta$, $\beta$-catenin, TCF7L2, and GLP-1 in the intestine were measured by western blotting. (J) The relative mRNA expression level of proglucagon, a precursor of GLP-1. Data are presented as the mean $\pm S D(n=5)$. Values with different superscript letters are significantly different at $\mathrm{p}<0.05$, compared with the control. ${ }^{*} \mathrm{P}<0.05$ for comparison between saline (NS) and $50 \%$ dextrose (D50), 20\% SMOFlipid (IL20) and 50\% dextrose+20\% SMOFlipid (Combination). AUC, area under the curve; CREB, cAMPresponseelement-bindingprotein; GAPDH, glyceraldehyde-phosphate-dehydrogenase; GLP-1, glucagon-like peptide-1-(7-36) amide; HOMA- $\beta$, homeostasis model assessment of $\beta$-cell function; HOMA-IR, homeostasis model assessment of insulin resistance; MMTT, mixed meal tolerance test; TCF7L2, transcription factor 7-like 2.

L-cells in case of glucolipotoxic conditions. ${ }^{19}$ Serial blood samples were collected for 2 hours after the consumption of a mixed meal to measure fasting and postprandial glucose, insulin, and C-peptide levels to evaluate insulin sensitivity and $\beta$-cell function. ${ }^{20}$ GLP-1 secretion was significantly decreased in chronic glucolipotoxicity condition. Infusions of D50, IL20, and combination for 6 hours caused insulin resistance and impaired $\beta$-cell function. The functional defects observed in these glucolipotoxic conditions involved coordinated inhibition of glucose-induced GLP-1 secretion, proglucagon biosynthesis, and GLP-1 related protein expressions. Rask et $a l^{21}$ demonstrated in a cohort of normal male subjects with varying degrees of insulin sensitivity that insulin resistance is negatively correlated with GLP-1 secretion. Proglucagon and PC1/3, an endopeptidase for GLP-1 production from proglucagon, are transcriptionally regulated by CREB. ${ }^{22}$ Decreased phosphorylation of GSK-3 $\beta$ and downregulation of $\beta$-catenin nuclear expression could, in turn, inhibit GLP-1 secretion. The secretion of active GLP-1 can be regulated at three stages: transcriptional regulation of the proglucagon gene, processing of the proglucagon protein into the active GLP-1, and the exocytosis of the GLP-1 vesicle. TCF7L2 has been known 
to control the transcription of the genes encoding GLP-1 and gastric inhibitory polypeptide (GIP) in the gut and brain. ${ }^{23}$ A recent study has revealed that TCF7L2 is critical for the regulation of proglucagon promoter activity. ${ }^{24}$ The GSK-3 $\beta / \beta$-catenin signaling has been documented to play an important role in TCF7L2 transcriptional activation. ${ }^{25}$ Our results indicate that the chronic glucolipotoxicity-induced downregulation of GSK-3 $\beta$, $\beta$-catenin, and TCF7L2 expression might account for the suppression of GLP-1.

There was no significant change in cell viability in chronic glucolipotoxic conditions. SGLT1 and GLUT2 are associated with electrical activity via the closure of $\mathrm{K}_{\text {ATP }}$ channels, and opening of voltage-dependent $\mathrm{Ca}^{+}$ channels. ${ }^{26}$ Compared with $5 \mathrm{mM} \mathrm{G}$, the protein levels of glucose transporters were $61 \%$ and $57 \%$ reduced under chronic glucolipotoxicity conditions, respectively. To determine whether glucose uptake was also affected under chronic glucolipotoxic conditions, we measured glucose uptake into L-cell and observed a $28 \%$ decrease in glucose uptake, indicating that glucose uptake decreased due to impaired expressions of glucose transporters. We could confirm a dominant-negative effect of the glucolipotoxic condition on GLP-1 secretion being regulated through the same glucose-sensing machinery as in $\beta$-cells. ${ }^{27}$ Consistent with these data, NADPH levels significantly decreased under chronic glucolipotoxicity conditions. Intracellular NADPH level increases, when glycolytic precursors or intermediates accumulate, and glucose-6-phosphate (G6P) is oxidized by G6P dehydrogenase $(\mathrm{G} 6 \mathrm{PDH})$, triggering commitment to the oxidative arm of the pentose phosphate pathway. ${ }^{26}$ Increased production of NADPH neutralizes ROS levels. ${ }^{27}$ We next ascertained that CD36 and TG were significantly increased, whereas PPAR $\alpha$ and ATP content were significantly reduced under chronic glucolipotoxic conditions.

The localization of the $\mathrm{K}_{\mathrm{ATP}}$ channel subunits, SUR1 and Kir6.2, to the gastrointestinal, endocrine L-cells indeed suggests that the GLP-1 secretion from these cells is regulated through the same glucose-sensing machinery as in the $\beta$-cells. ${ }^{28}$ It is of interest that the expressions of the SUR1 and the KCNJ11/Kir6.2 genes, both coding for central parts of the $\mathrm{K}_{\mathrm{ATP}}$ channels, ${ }^{29}$ significantly decreased in chronic glucolipotoxic condition. The Zucker Diabetic Fatty rat showed a decreased expression of Kir6.2 mRNA compared with lean control rats, ${ }^{30}$ and Kir6.2 mRNA levels dropped by $40 \%$ in pancreatectomized, highly hyperglycemic rats, but were nearly unaffected in only mildly hyperglycemic rats. ${ }^{31}$ Moritz et al demonstrated that changes in SUR1 transcript levels induced by glucose were reflected by parallel changes in SUR1 protein levels. ${ }^{32}$ Recent studies have indicated an association between type 2 diabetes and polymorphisms in these genes as well as in the SLC2A2/ GLUT2 gene. $^{29} 33$ The major intracellular functions of cAMP are transduced by PKA and exchange proteins directly activated by cAMP (EPACs).$^{34}$ The observation that glucose-induced cAMP signaling is suppressed in palmitate-treated cells is consistent with previous findings that the secretory defect involves a late step in stimulussecretion coupling. ${ }^{35}$ CaMKII has also been suggested to promote $\mathrm{Ca}^{2+}$-dependent intracellular $\mathrm{Ca}^{2+}$ release. ${ }^{36}$ Increases of cAMP amplify insulin secretion both via PKA and the guanine nucleotide exchange factor Epac. These results suggest that chronic glucolipotoxicity impairs GLP-1 secretion by suppressed cAMP signaling. Chronic glucolipotoxic conditions significantly increased ROS production. Ceramides inhibit the mitochondrial electron transport chain, thereby increasing the generation of ROS. ${ }^{37}$ However, there was no significant difference in ceramide levels in chronic glucolipotoxicity condition in our study. Since UCP2 modulates the efficiency of ATP production ${ }^{38}$ by catalyzing the translocation of protons across the mitochondrial membrane, one could expect changes in oxidative ATP synthesis. Complex I is the primary electron entry point in the mitochondrial electron transport chain ${ }^{39}$ and is the major site for the cellular production of ROS via the formation of superoxide anion. ${ }^{40}$ Superoxide radical, the parental form of intracellular ROS, is a very reactive molecule. It can be converted to hydrogen peroxide by SOD isoenzymes, and then to oxygen and water by several enzymes including catalase and glutathione. In our study, an increase in UCP2 could decrease the ATP production by uncoupling the mitochondrial oxidative phosphorylation, thereby decreasing GLP-1 secretion with associated changes in glucose and lipid metabolism in L-cells.

Glucolipotoxicity contributes to $\beta$-cell failure in a time-dependent manner. Insulin secretion was recovered by simultaneous treatment with Ex-4 but not by recovery time. The pancreatic $\beta$-cells is a known target of GLP-1 action, releasing insulin in a glucose-dependent fashion. ${ }^{41}$ Impaired insulin secretion preceded the decrease in GLP-1 secretion under the same stimulation conditions. GLP-1 secretion appears to be reversible by recovery time and insulin cotreatment. Insulin has been reported to stimulate proglucagon gene expression, as well as GLP-1 synthesis, in GLUTag cells through an Akt-glycogen synthase kinae-3 pathway that involves the bipartite transcription factor, $\mathrm{T}$ cell transcription factor$4{ }^{42}$ In addition, it was possible to discover the association between $\beta$-cell toxicity and L-cell toxicity as well as the potential complementarity between them through coculture study. MEK-ERK1/2 pathway was demonstrated to mediate insulin-induced GLP-1 secretion from the $\mathrm{L}$ cells ${ }^{15}$ and insulin release from the $\beta$-cell. ${ }^{43} \mathrm{We}$ have reported that metformin directly stimulated GLP-1 production and secretion through cross-talk between the insulin and Wnt signaling pathway, in which we also observed the increased expressions of SGLT1 by metformin. ${ }^{44}$ It is also very interesting to see that a negative effect of the glucolipotoxic conditions on GLP-1 secretion affected similar mechanisms as in $\beta$-cells, and it warrants further study whether the Wnt signaling would also be affected by the glucotoxicity and/or lipotoxicity and whether glucolipotoxicity could be prevented 
by GLP-1 or insulin in vivo, and the pathophysiological implications during the development of type 2 diabetes or insulin in L-cells.

The correlation between microbiota changes and GLP-1 secretion was also reported, ${ }^{45}$ and it warrants further study whether the gut microbiota would be affected by the glucolipotoxicity and whether there is any correlation between the changes in gut microbiota and GLP-1 secretion in our model.

Although the clinical trials that the glucolipotoxicity affects GLP-1 were not performed, it was reported that GLP-1 secretion is reduced in patients with type 2 diabetes, ${ }^{46-48}$ and this may contribute in part to the reduced incretin effect and the hyperglycemia that is observed in these individuals. ${ }^{49}$ Thus, interest has now focused on the factors that regulate the release of this peptide after nutrient ingestion. ${ }^{50}$

The novelties of our work are that we induced glucolipotoxicity in a nondiabetic animal model, which was associated with the decreased Wnt/ $\beta$-catenin/TCF7L2 system that could lead to the decreased GLP-1 transcription and secretion and that the glucolipotoxicity could potentially be prevented by coculture with insulin-producing cells. Considering that the chronic glucolipotoxicity condition we set up is a mimicry of diabetic pathology, ${ }^{18}$ our results might suggest several strategies to overcome glucolipotoxicity of both L-cells and $\beta$-cells which could be applied in clinical practice.

These results suggest interesting insights on the glucolipotoxicity of L-cells both in vitro and in vivo and some of the mechanisms.

Contributors $\mathrm{J}-\mathrm{HH}$ and $\mathrm{D}-\mathrm{HK}$ performed the research and analyzed and interpreted the experiments. J-HH wrote the manuscript and M-KL edited the manuscript. M-KL is the guarantor of this work and as such had full access to all the data in the study and takes responsibility for the integrity of the data and the accuracy of the data analysis.

Funding This work was supported by a Samsung Biomedical Research Institute of Korea Grant (OTC1190171).

Competing interests None declared.

Patient consent for publication Not required.

Ethics approval This study was reviewed and approved by the Institutional Animal Care and Use Committee (IACUC) of the Samsung Biomedical Research Institute (SBRI No. 0TC1190171, Seoul, South Korea). SBRI is an Association for Assessment and Accreditation of Laboratory Animal Care International (AAALAC International) accredited facility and abide by the Institute of Laboratory Animal Resources (ILAR) guide.

Provenance and peer review Not commissioned; externally peer reviewed.

Data availability statement Data are available on reasonable request. All data relevant to the study are included in the article.

Open access This is an open access article distributed in accordance with the Creative Commons Attribution Non Commercial (CC BY-NC 4.0) license, which permits others to distribute, remix, adapt, build upon this work noncommercially, and license their derivative works on different terms, provided the original work is properly cited, appropriate credit is given, any changes made indicated, and the use is non-commercial. See: http://creativecommons.org/ licenses/by-nc/4.0/.

\section{REFERENCES}

1 Meloni AR, DeYoung MB, Lowe C, et al. Glp-1 receptor activated insulin secretion from pancreatic $\beta$-cells: mechanism and glucose dependence. Diabetes Obes Metab 2013;15:15-27.

2 Kjems LL, Holst JJ, Vølund A, et al. The influence of GLP-1 on glucose-stimulated insulin secretion: effects on beta-cell sensitivity in type 2 and nondiabetic subjects. Diabetes 2003;52:380-6.

3 Chang AM, Jakobsen G, Sturis J, et al. The GLP-1 derivative NN2211 restores beta-cell sensitivity to glucose in type 2 diabetic patients after a single dose. Diabetes 2003;52:1786-91.

4 Jang H-J, Kokrashvili Z, Theodorakis MJ, et al. Gut-expressed gustducin and taste receptors regulate secretion of glucagon-like peptide-1. Proc Natl Acad Sci U S A 2007;104:15069-74.

5 Deacon CF. Circulation and degradation of GIP and GLP-1. Horm Metab Res 2004;36:761-5.

6 Rodbard HW, Jellinger PS, Davidson JA, et al. Statement by an American association of clinical Endocrinologists/American College of endocrinology consensus panel on type 2 diabetes mellitus: an algorithm for glycemic control. Endocr Pract 2009;15:540-59.

7 Prentki M, Joly E, El-Assaad W, et al. Malonyl-Coa signaling, lipid partitioning, and glucolipotoxicity: role in beta-cell adaptation and failure in the etiology of diabetes. Diabetes 2002;51 Suppl 3:S405-13.

8 Poitout V, Robertson RP. Minireview: Secondary beta-cell failure in type 2 diabetes--a convergence of glucotoxicity and lipotoxicity. Endocrinology 2002;143:339-42.

9 Reimann F, Gribble FM. Glucose-Sensing in glucagon-like peptide1-secreting cells. Diabetes 2002;51:2757-63.

10 Reimann F, Habib AM, Tolhurst G, et al. Glucose sensing in L cells: a primary cell study. Cell Metab 2008;8:532-9.

11 Calanna S, Christensen M, Holst JJ, et al. Secretion of glucagon-like peptide-1 in patients with type 2 diabetes mellitus: systematic review and meta-analyses of clinical studies. Diabetologia 2013;56:965-72.

12 Kornelius E, Li H-H, Peng C-H, et al. Liraglutide protects against glucolipotoxicity-induced RIN-m5F $\beta$-cell apoptosis through restoration of Pdx1 expression. J Cell Mol Med 2019;23:619-29.

13 Liu Z, Stanojevic V, Brindamour LJ, et al. GLP1-derived nonapeptide GLP1(28-36)amide protects pancreatic $\beta$-cells from glucolipotoxicity. $J$ Endocrinol 2012;213:143-54.

14 Lim GE, Huang GJ, Flora N, et al. Insulin regulates glucagon-like peptide-1 secretion from the enteroendocrine $L$ cell. Endocrinology 2009;150:580-91.

15 de Bruïne AP, Dinjens WN, van der Linden EP, et al. Extracellular matrix components induce endocrine differentiation in vitro in NCl-H716 cells. Am J Pathol 1993;142:773-82.

16 Lowry $\mathrm{OH}$, Rosebrough NJ, Farr AL, et al. Protein measurement with the Folin phenol reagent. J Biol Chem 1951;193:265-75.

17 De Luca T, Szilágyi KL, Hargreaves KA, et al. Improving the patency of jugular vein catheters in Sprague-Dawley rats by using an antiseptic nitrocellulose coating. J Am Assoc Lab Anim Sci 2018;57:520-8

18 Poitout V, Robertson RP. Glucolipotoxicity: fuel excess and beta-cell dysfunction. Endocr Rev 2008;29:351-66.

19 Koepsell H. Glucose transporters in the small intestine in health and disease. Pflugers Arch 2020;472:1207-48.

20 Paglialunga S, Guerrero A, Roessig JM, et al. Adding to the spectrum of insulin sensitive populations for mixed meal tolerance test glucose reliability assessment. J Diabetes Metab Disord 2016;15:57-60.

21 Rask E, Olsson T, Söderberg S, et al. Insulin secretion and incretin hormones after oral glucose in non-obese subjects with impaired glucose tolerance. Metabolism 2004;53:624-31.

22 Lee J-H, Wen X, Cho H, et al. CREB/CRTC2 controls GLP1-dependent regulation of glucose homeostasis. Faseb $J$ 2018;32:1566-78.

23 Yi F, Brubaker PL, Jin T. Tcf-4 mediates cell type-specific regulation of proglucagon gene expression by beta-catenin and glycogen synthase kinase-3beta. J Biol Chem 2005;280:1457-64.

24 Shao W, Wang D, Chiang Y-T, et al. The Wnt signaling pathway effector TCF7L2 controls gut and brain proglucagon gene expression and glucose homeostasis. Diabetes 2013;62:789-800.

$25 \mathrm{Jin}$ T. The Wnt signalling pathway and diabetes mellitus. Diabetologia 2008;51:1771-80.

26 Park J, Lee I-S, Kim K-H, et al. Gi inflammation increases sodiumglucose cotransporter SGLT1. Int J Mol Sci 2019;20:2537-50.

27 Patra KC, Hay N. The pentose phosphate pathway and cancer. Trends Biochem Sci 2014;39:347-54.

28 Nielsen LB, Ploug KB, Swift P, et al. Co-localisation of the Kir6.2/ SUR1 channel complex with glucagon-like peptide-1 and glucosedependent insulinotrophic polypeptide expression in human ileal 
cells and implications for glycaemic control in new onset type 1 diabetes. Eur J Endocrinol 2007;156:663-71.

29 van Dam RM, Hoebee B, Seidell JC, et al. Common variants in the ATP-sensitive $\mathrm{K}^{+}$channel genes KCNJ11 (Kir6.2) and ABCC8 (SUR1) in relation to glucose intolerance: population-based studies and meta-analyses. Diabet Med 2005;22:590-8.

30 Tokuyama Y, Fan Z, Furuta $\mathrm{H}$, et al. Rat inwardly rectifying potassium channel Kir6.2: cloning electrophysiological characterization, and decreased expression in pancreatic islets of male Zucker diabetic fatty rats. Biochem Biophys Res Commun 1996;220:532-8.

31 Jonas JC, Sharma A, Hasenkamp W, et al. Chronic hyperglycemia triggers loss of pancreatic beta cell differentiation in an animal model of diabetes. J Biol Chem 1999;274:14112-21.

32 Moritz W, Leech CA, Ferrer J, et al. Regulated expression of adenosine triphosphate-sensitive potassium channel subunits in pancreatic beta-cells. Endocrinology 2001;142:129-38.

33 Barroso I, Luan J, Middelberg RPS. Candidate gene association study in type 2 diabetes indicates a role for genes involved in B-cell function as well as insulin action. PLOS Biol 2003;1:41-55.

34 Almahariq M, Mei FC, Cheng X. Cyclic AMP sensor Epac proteins and energy homeostasis. Trends Endocrinol Metab 2014;25:60-71.

35 Olofsson CS, Collins S, Bengtsson M, et al. Long-Term exposure to glucose and lipids inhibits glucose-induced insulin secretion downstream of granule fusion with plasma membrane. Diabetes 2007;56:1888-97.

36 Jung S-R, Reed BJ, Sweet IR. A highly energetic process couples calcium influx through L-type calcium channels to insulin secretion in pancreatic beta-cells. Am J Physiol Endocrinol Metab 2009;297:E717-27.

37 Zigdon H, Kogot-Levin A, Park J-W, et al. Ablation of ceramide synthase 2 causes chronic oxidative stress due to disruption of the mitochondrial respiratory chain. J Biol Chem 2013;288:4947-56.

38 Klingenberg M, Huang SG. Structure and function of the uncoupling protein from brown adipose tissue. Biochim Biophys Acta 1999;1415:271-96.
39 Andrews B, Carroll J, Ding S, et al. Assembly factors for the membrane arm of human complex I. Proc Natl Acad Sci U S A 2013;110:18934-9.

40 Hirst J, King MS, Pryde KR. The production of reactive oxygen species by complex I. Biochem Soc Trans 2008;36:976-80.

41 Drucker DJ. The biology of incretin hormones. Cell Metab 2006;3:153-65.

42 Edwards CM, Todd JF, Mahmoudi M, et al. Glucagon-Like peptide 1 has a physiological role in the control of postprandial glucose in humans: studies with the antagonist exendin 9-39. Diabetes 1999;48:86-93.

43 Longuet $\mathrm{C}$, Broca $\mathrm{C}$, Costes $\mathrm{S}$, et al. Extracellularly regulated kinases $1 / 2$ (p44/42 mitogen-activated protein kinases) phosphorylate synapsin I and regulate insulin secretion in the MIN6 beta-cell line and islets of Langerhans. Endocrinology 2005;146:643-54.

$44 \mathrm{Kim} \mathrm{M}-\mathrm{H}$, Jee J-H, Park S, et al. Metformin enhances glucagonlike peptide 1 via cooperation between insulin and Wnt signaling. $J$ Endocrinol 2014;220:117-28.

45 Cornejo-Pareja I, Martín-Núñez GM, Roca-Rodríguez MM, et al. H. pylori Eradication Treatment Alters Gut Microbiota and GLP-1 Secretion in Humans. J Clin Med 2019;8:451-67.

46 Toft-Nielsen MB, Damholt MB, Madsbad S, et al. Determinants of the impaired secretion of glucagon-like peptide-1 in type 2 diabetic patients. J Clin Endocrinol Metab 2001;86:3717-23.

47 Vilsbøll T, Agersø H, Krarup T, et al. Similar elimination rates of glucagon-like peptide-1 in obese type 2 diabetic patients and healthy subjects. J Clin Endocrinol Metab 2003;88:220-4.

48 Mannucci E, Ognibene A, Cremasco F, et al. Glucagon-like peptide (GLP)-1 and leptin concentrations in obese patients with Type 2 diabetes mellitus. Diabet Med 2000;17:713-9.

49 Nauck M, Stöckmann F, Ebert R, et al. Reduced incretin effect in type 2 (non-insulin-dependent) diabetes. Diabetologia 1986;29:46-52.

50 Lim GE, Brubaker PL. Glucagon-Like peptide 1 secretion by the Lcell. Diabetes 2006;55:S70-7. 